\title{
The Role of Health Promotion on Smoke Free Area Implementation at Regional Work Unit Langsa City
}

\author{
Maswita $^{1}$, Etti Sudaryati ${ }^{2}$, Juanita ${ }^{2}$ \\ ${ }^{1}$ Master Student in Faculty of Public Health, Universitas Sumatera Utara, Medan, Indonesia \\ ${ }^{2}$ Lecturer in Faculty of Public Health, Universitas Sumatera Utara, Medan, Indonesia \\ Email: witaptm@gmail.com
}

\begin{abstract}
:
Smoke free area implementation is one of the effective efforts to protect people from cigarette smoke. Health promotion can improve community behavior until they want and able to do healthy behavior and free from health problems. This study aims to explore the role of health promotion that has been implemented by the Langsa City Health Office in relation of smoke free area implementation, especially in regional work unit (SKPK). This is a qualitative study with narrative research design. Data are collected by indepth interview. The results show the role of the health promotion has been done in the implementation of the smoke free area are controlling social or environmental changes in the workplace through advocacy, socialization, development of promotional media, and monitoring and evaluation of smoke freea area implementation. The conclusion of this study that health promotion plays an important role in implementing the smoke free area including advocacy with regional government, disseminate information about the hazard of cigarettes to the public, set a regional regulation and socializing Qanun regarding smoke free area, and carried out smoke free area evaluation meeting to the head of regional work unit for commitment and support the smoke free area implementation at workplace.
\end{abstract}

Keywords:

health promotion; smoke free area implementation; workplace

\section{Introduction}

Every health problem, generally caused by three factors that arise simultaneously, that are (1) the existence of other germs or disruptors, (2) the existence of an environment that allows the development of germs, and (3) the behavior of community not care about germs and the environment. Health and illness are largely determined by the human behavior. The behavior change problem is related to the effort of Health Promotion. Health Promotion is regulated in the Ministry of Health Regulation No. 1114 / Menkes / SK / VII / 2005 about Guidelines for Implementing Health Promotion in the Regions. Health Promotion is an effort to improve the ability of the community through learning from, by, for and with the community, so that they can help themselves, and develop activities that are communitybased, in accordance with local socio-cultural conditions and supported by public healthminded policies.

The implementation of health promotion, must be strengthened by (1) the right methods and media, and the availability of (2) adequate resources. Management of health promotion should be headed by a coordinator who has the capacity in Health Promotion. The Health Promotion Coordinator is an experts health promotion as the functional public health education officer.

Cigarette is one of the biggest causes of death in the world. It is estimated up to 2030 deaths due to cigarettes will reach 10 million per year. In Indonesia, smoking problems are a national problem that is continuously being overcome. 
The results of Riskesdas (2013) in NAD Province, based on smoking behavior, prevalence of population of 10 years and over smokers every day in Langsa City is $20.8 \%$. The prevalence of smokers in homes when with household members for Langsa City is $92.5 \%$.

Smoking not only affects people who smoke, but also affects non-smokers around and known as second-hand smoker. Community have the right to live in a healthy environment and have the right to be protected from other people's smoke exposure. There is no safe limit for cigarette smoke exposure. Toxins contained in ciggarette smoke can accumulate in the body and cause various health problems.

The government has set a smoke free area policy to protect community from cigarette smoke hazard through law No. 36 of 2009 on health article 115 paragraph 1 and 2 that mandates to the Regional government (obligatory) to establish and implement smoke free area in its region.

In terms of supporting the development of region smoke free area in the form of smoke free area policy, a joint regulation of The Ministry of Health and The Ministry of Home Affairs No. 188 / Menkes / PB / 1/2011-number 7 of 2011 about Guidelines for the Implementation of smoke free area, followed by The Ministry of Home Affairs letter No. 440/885 / SJ dated March 22, 2011. In article 3 paragraph (1) smoke free area include; health service facilities, teaching and learning processes place, children's playground, worship place, public transportation, workplaces, public places and other places stipulated in paragraph (2). The leader or responsible person of the places as referred to in paragraph (1) must determine and implement smoke free area.

Smoke free area is the responsibility of all components of the nation, community, individuals, House of Representatives or Regional House of Representatives, central and regional governments to protect current and future generations from the cigarette smoke hazards that consists of 250 toxic and carcinogenic compounds. Smoke free area implementation is one of the effective efforts to protect community from other people's cigarette smoke.

Langsa City has issued Qanun No.1 of 2015 concerning smoke free area as a manifestation of creating a clean, healthy and comfortable living environment. The Health Office have to responsible for the smoke free area implementation in Langsa City. The role and effort of health promotion as a policy component in smoke free area implementation is very important. Smoke free area implementation is expected to be able to improve the community health status, especially to control risk factors and diseases and deaths caused by ciggarette smoke and also improving the culture of the community in a clean and healthy lifestyle.

From the description above, the problem in this study is to explore the role of health by the Health Promotion Program of the Langsa City Health Office on smoke free area implementation in the Region Work Unit.The purpose of this study is to analyze the role of health promotion that has been implemented by the Langsa City Health Office in relation of smoke free area implementation in Langsa City, especially in regional work unit. 


\section{Research Method}

This study uses descriptive qualitative research methods with narrative research design. Research location at Langsa City Health Office. The informants in this study were employees in the Health Promotion Section of the Langsa City Health Service, Head of the Langsa City Health Promotion section and Head of the Public Health Division at the Langsa City Health Office. The research instrument in this study was the researchers themselves with additional tools in the form of stationery, questionnaires. Data are collected by indepth interview technique. Data analysis is done to compare the results of research with existing theories with the stages of interview data collection, the reduction phase, the presentation stage, the stage of drawing conclusions.

\section{Result and Discussion}

\subsection{Results}

The Health Promotion Section is under the Public Health Sector, in this section there are 5 members, consisting of 1 Section Head, 1 person Public Health Extension Functional Position staff and 3 other ordinary structural personnel.

The Health Promotion section has carried out three health promotion strategies in its activities including advocating to the Mayor and the Regional Representative Council to obtain support for smoke free area policies. Advocacy was carried out in 2014 and sparked Qanun No.1 of 2015.

The results of interviews and observations to the Health Promotion section of the Langsa City Health Office to the role of Health Promotion in the application of smoke free area in the RegionalWork Unit are explained below:

\section{Advocacy Efforts}

Interviewed by Informant $\mathrm{S}$, it was stated that advocacy efforts had been carried out with the Government in this case the mayor and Regional House of Representatives in 2014 and stipulated regional regulations that is Qanun No.1 of 2015 concerning smoke free area. Research by Budiono (2010) states that stakeholders have a strong influence and are highly related in advocacy efforts. According to Harpeni (2015), it was revealed that Advocacy Methods were quite effective to be used to influence government policies.

\section{Media Development and Facilities}

Informant D said that the Health Promotion program had made the smoke free area promotion media in the form of standing banner distributed to the Regional Work Unit (SKPK) in Langsa City and in Health Services such as Hospitals, Health Centers and Health Clinics. Smoke free area banners and billboards installation at the health center. Stickers and Keychains distribution in open public places in Langsa City.

Health promotion facilities and infrastructure such as Promkes Cars, Over Head Projector (OHP), wireless microphones, tape/cassette recorders/ players are sufficed. Harpeni (2015) from the results of research conducted with qualitative methods showing the installation of media socialization of smoke free area will require sufficient time to measure the effectiveness of the media. Harpeni (2015) conducted research with qualitative methods showing that the installation of socialization media for smoke free areas would require sufficient time to measure the effectiveness of the media. 


\section{Smoke Free Area Implementation}

According to Informant M, socialization of Qanun No.1 2015 concerning smoke free area was carried out in 2016, inviting 450 participants in 10 phases, the participants of the activity consisted of Head of Regional Work Unit, Chief of Sub-district, Sub-district Secretary, University Rectors, Headmaster of Kindergarten to High School, Dayah Leader, Head of Land Transportation Organization, Head of Market, Chairman Counter, Village Priest, Head of Youth Organization, Hotel Owner, Non-Governmental Organizations (NGOs), StateOwned Enterprises, Head of Orphanage, Head of Health Laboratory, Head of Regional and Private Hospitals, Health Clinics, Private Institutions and Head of Community Health Centers in Langsa City.

Informant $\mathrm{M}$ said that the Langsa City Government is committed to implementing a smoke free area. In July 2017 Langsa City received Pastika Parahita award from the Ministry of Health. This commitment is reflected in increasing understanding and knowledge of the community regarding regulations on smoke free area and prevention of non-communicable diseases caused by the risk of tobacco consumption.

\section{Monitoring and Evaluating Smoke Free Area Implementation}

Based on interviews with informant M, explained in June 2018 they evaluated the smoke free area implementation in the Regional Work Unit or Langsa City Government, Health Service Centers and Schools. The evaluation results show that all Regional Work Unit know about smoke free area $(100 \%)$. There are $95 \%$ of Regional Work Unit have informed the Qanun of smoke free area to all staff in the workplace and only 5\% of that did not. $40 \%$ of Regional Work Unit have provided smoking area and 60\% do not have a smoking area. $35 \%$ of Regional Work Unit have put up smoking ban information boards, and $65 \%$ of them not have smoking ban information boards. Only 5\% of Regional Work Unit have assigned an officer related to smoke free area implementation and the remaining, 95\% have not assigned an officer to arrange smoke free area. There are 35\% of Regional Work Unit have sanctioned smoking outside the smoking area and $65 \%$ have no sanctions against violators. $75 \%$ of Regional Work Unit states that the smoke free area policy is effective and $25 \%$ of Regional Work Unit states ineffective. The evaluation results show that some Regional Work Unit have not assigned a smoke free area officer due to the lack of information on the Indicators of smoke free area implementation.

\subsection{Discussion}

\section{a. Health Promotion Role}

Three basic strategies for health promotion are; Advocacy, Community Development and Community Empowerment Movement. The role of health promotion to create a healthy workplace in accordance with the regulation of the Ministry of Health Number 161/menkes/ins/III/1990 about smoke free workplace.

\section{b. Smoke Free Area Implementation at Regional Work Unit}

Evaluation results by the smoke free area monitoring team of Langsa City Health Office as implementers of the smoke free area policy were found that the implementation of the smoke free area in the Regional Work Unit is implemented properly. Government supports in funding and regulation has made smoke free area implementation goes according to plan, however some Regional Work Unit has not assigned a smoke free monitoring team. Commitments and follow-up plans have been prepared at smoke free evaluation meeting to mobilize smoke free area implementation at workplace. According to Azka (2013) states that smoke free area without commitment and support of society element will be difficult, the 
smoke free area implementation allows to provide protection to passive smokers and allows to reduce active smokers. The Langsa City Government clearly supports the smoke free area policy due to its benefits to reduce smoking-related diseases. Sayuti (2017) explained that there was evidence that the application of smoke free area was known from the level of compliance of staff and visitors to Public Health Center and sanction applied for dismemberment of incentives who violated smoking bans in smoke free area.

\section{Conclusion}

Based on the results of the study, it was concluded that the role of health promotion in smoke free area implementation in the Regional Work Unit were:

1. Advocating related to the smoke free area policy in the Regional Government.

2. Disseminate information about the dangers of cigarettes to the public.

3. Set a Qanun /Regional regulations regarding smoke free area.

4. Socializing Qanun No.1 of 2015 concerning smoke free area

5. Conduct Monitoring and Evaluation related to the smoke free area implementation

6. Make a smoke free area evaluation meeting at the Head of the City Work Unit for commitment and support for the implementation of the smoke free area to implement it in accordance with the indicators of the smoke free area in workplace.

\section{Acknowledgements}

Thanks to my lecturers for all of support in helping me to finish my research. Special appreciation to the Health Office in Langsa City and Head of Regional Work Unit for giving me permission and my gratitude to all of the informants.

\section{References}

Kementrian Kesehatan RI, Pedoman Pengembangan Kawasan Tanpa Rokok, Pusat Promosi Kesehatan (2011).

Peraturan bersama Menteri Kesehatan dan Menteri dalam Negeri No.188/Menkes/PB/1/2011 No.7 Tahun 2011.

Peraturan Pemerintah RI No.19 Tahun 2003 tentang pengamanan Rokok bagi kesehatan. Qanun No.1 tahun 2015 tentang Kawasan Tanpa Rokok.

Kemenkes (2013).Riset Kesehatan dasar.Kemenkes.

Direktorat Jenderal Pengendalian Penyakit dan Penyehatan Lingkungan, Direktorat Pengendalian Penyakit Tidak menular.(2015). Hidup Sehat Tanpa Rokok. Jakarta :

Kementerian Kesehatan RI

Aditama, T.Y. (2011). Rokok dan Kesehatan. Jakarta: UI Press.

Cipta, 2010. Promosi Kesehatan dan Perilaku Kesehatan.Jakarta:Rineka Cipta.

Sugiyono.2013.Metode Penelitian Kuantitatif, Kualitatif, dan Kombinasi.Bandung:Alfabeta

Kemn, J. \& Close, A (1995) Health Promotion. Theory and Practice, Mackays of Chatham PLC, Chatham, Kent: Great Britain.

Harpeni Siswatibudi (2015), Program Promosi Kesehatan dalam Upaya Penerapan Kawasan 100\% Bebas Asap Rokk di Fakultas Kedokteran Universitas Gadjah Mada, Jurnal Permata Indonesia:Volume 6.

Notoadmodjo, S.(2005). Metodologi Penelitian. Jakarta: Rineka Cipta. .(2007). Promosi Kesehatan dan Ilmu Perilaku. Jakarta: Rineka Cipta. .(2010). Promosi Kesehatan. Teori dan Aplikasi. Edisi Revisi. Jakarta:

Rineka Cipta. 
Notoadmodjo, S.(2005). Metodologi Penelitian. Jakarta: Rineka Cipta.

Sari.(2016). Dalam sebatang rokok terkandung sekitar 4000 macam zat kimia. diakses 17 Pebruari 20176 dari http://nurrjannahps.blogspot.co.id/ 2016/01/5.html.

Suleiman, R., \& Muhammad. (2016). Penyebab Utama Makin Banyak Perokok di Indonesia. diakses 27 April 2017 https://health.detik.com/read/2016/05/31/ 190503/3222227/763/3penyebab-utama-makin-banyak-perokok-di-indonesia-iklanmudah-dan-murah.

Budiono, Jati S, dan Musthofa S, 2010. Posisi Stakeholder Dan Strategi Advokasi Kibbla Kabupaten/Kota Di Jawa Tengah. Jurnal Manajemen Pelayanan Kesehatan

Fathorrahman, 2017. Terapkan Kawasan Tanpa Rokok, Langsa raih penghargaan dari Menkes. MediaAceh.co. diakses 23 Oktober 2018 dari mediaaceh.co

Azkha, N. (2013). Studi Efektivitas Penerapan Kebijakan Perda Kota tentang Kawasan Tanpa Rokok (KTR) Dalam upaya Menurunkan Perokok Aktif Di Sumatera Barat Tahun 2013. Jurnal Kebijakan Kesehatan Indonesia. 